
1

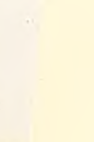

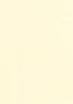
.

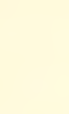

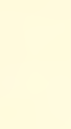

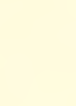

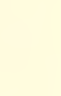

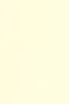
.

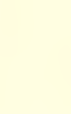

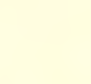

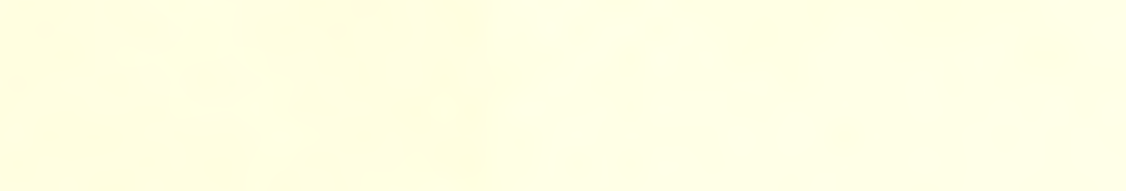

$+$
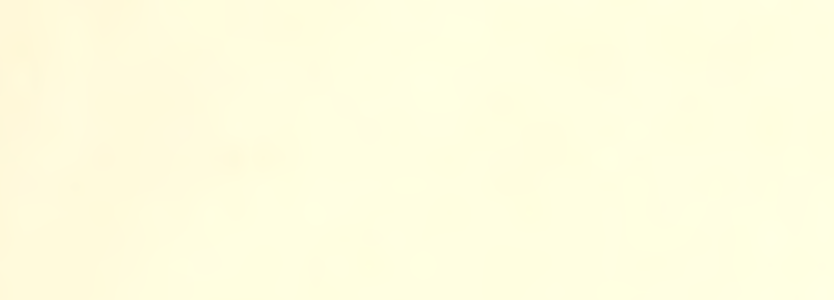
.
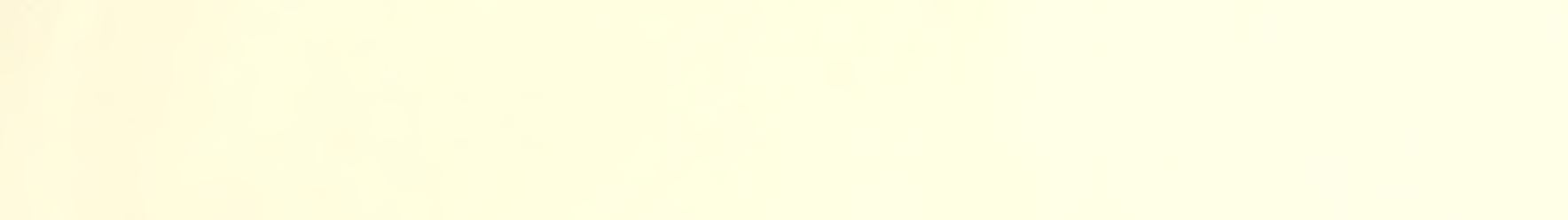

.





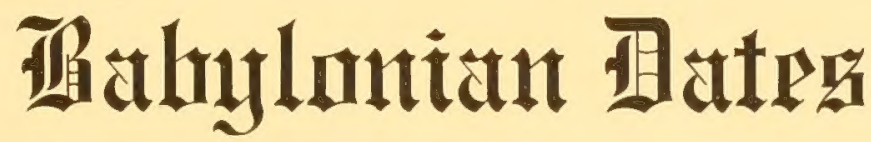

fur Ualifurnia

PAUL B. POPENOE 
$\because$ 


\title{
Babylonian Dates for California
}

\author{
PAUL B. POPENOE \\ EDITOR OF THE JOURNAL OF HEREDITY, WASHINGTON, D. C.
}

The greatest date-growing region in the world is the country between Mesopotamia and the Persian Gulf, which is now properly called 'Iraq and is a part of Turkey in Asia, but which I shall call by its ancient name of Babylonia, as more familiar to Oceidentals. Its dates, which we have been accustomed inaccurately to call "Persian Gulf dates," have long held a practical monopoly of the American market; but when the culture of the palm began to be taken up seriously by California ranchers, they drew nearly all their stock from Algeria, because of the greater accessibility of the North African oases.

Most of the varieties thus secured, however, are late in maturing, and when they became well established, it was realized that an extension of the season, by the addition of earlier varieties, would be of great value to the industry here. Late dates like Deglet Núr do not get into market until the fresh importations from Babylonia have arrived, and they must compete with a flood of fruit which can be laid down in the United States for less than five cents a pound. If, however, California growers can market a considerable portion of their crop in August and September, they will have a market empty of dates, when any good fruit will find a ready sale at a remunerative figure.

It was known in a general way that the Babylonian varieties would meet this need. The Bureau of Plant Industry of the United States Department of Agriculture had introduced a number of them on an experimental scale, following a visit of David Fairchild to the region in 1903, and among the varieties thus secured were several that ripened earlier than anything theretofore known in the United States. In fact, Arizona growers did not hesitate to say that the "Persian Gulf" varieties would practically be the making of the industry in their state, ${ }^{*}$ since the best from Algeria matured at a time at which the crop was usually ruined by rain.

Under these circumstances, the West India Gardens, of Altadena, Los Angeles County, California, sent me to the region in question, to spend the winter of 1912-1913, make as full a study of the date varieties as possible, and introduce the best of them to the United States on a large scale. I began with a visit to the home of the Fardh date in Oman, $\dagger$ on the eastern coast of Arabia, and then spent nearly four months in Busreh, near the head of the Persian gulf, and Baghdád, 500 miles farther north. In this region I was able to list 112 varieties of dates, deseriptions of most of which, including

* Popenoe, Paul B., in Bul. Calif. Comm. Hort., I, 10, p. 877. The Arizonans have since come to prefer Egyptian dates.

† Popenoe, Paul B., in Bul. Calif. Comm. Hort., Jan., 1914. 
even many of the best, have never before been published, and to bring to California 9,000 offshoots, which arrived in remarkably good condition and are now divided between many growers in the Coachella Valley and elsewhere.

It is my purpose in this paper to describe the varieties of dates grown in Babylonia, not only for the importance which such descriptions will necessarily possess for Californians growing the varieties in question, but as a guide for future visitors to that region; for $\mathrm{I}$ believe it is the most promising known, from which to draw a large supply of high-grade offshoots for the United States.

Although the dates of Busreh are better known, and more important commercially, and are now and always have been* considered, even by Arabs, as the best, my opinion-as is that of my brother, F. W. Popenoe, who accompanied me, and to whom I am indebted for much assistance in preparing descriptions - is that the Baghdád field is incomparably richer. Commereialism at Busreh has tended to restrict planting to the three great export varieties, Haláwí, Khadhráwí and Sáyir, and none of these can be considered a superfine date, although for a steady diet Khadhráwí is as satisfactory as any grown. Yet Haláwí is more profitable, since its lighter color makes it a favorite in the American market. The price received for this variety by growers in 1912 (when the crop was large) was $\$ 2.22$ per maund of 153 pounds. The prices of Haláwí, Khadhráwí and Sáyir, respectively, were in that year as $320: 260: 220$. There is, thus, no doubt as to what is the most profitable date at Busreh, the choicest varieties, like 'Awaydí and Barhí, being cultivated to a very limited extent indeed.

In Baghdád the dry date Záhidí is most widely cultivated, and there are no virtues which growers do not ascribe to it. There are many finer ones, but Záhidí has come to be the choice of the nomad tribes who are the chief consumers of Baghdád dates, and as it is early, hardy, vigorous, and unusually prolific, the growers plant it so largely that many groves contain nothing else. It is usually considered the most profitable there, but some growers put Khustáwi ahead of it, because of the higher price it commands, in spite of its lighter yield; Asharasí, Maktúm and Tabirzál probably come next in order, but the last two are hardly cultivated on a commerial scale and, as a matter of fact, one sees Busreh Khadhráwis sold in the Baghdád bazar more frequently than any of the local varieties.

The first ripe dates are eaten by the natives in July, but it must be admitted that an Arab will eat dates when they are still so hard and full of tannin that American hogs would hardly touch them. Perhaps August first might be taken as the commencement of the date season in an average year, while it is not in full swing until a month or six weeks later. Within a month all of the prineipal varieties have been picked and sold; in forty days the

* Besides medieval Arab writers, ef. Marco Polo's description in the latter half of the 13th century, "There is also on the river (Tigris) as you go from Baudas (Baghdád) to Kisi (Kish) a great city called Bastra (Busreh; classically Basreh), surrounded by woods, in which grow the best dates in the world."-Yule's Ed., I, 60, London, 1871.

$$
\begin{aligned}
& \text { Citin } \\
& \text { inthor } \\
& \text { sorwon }
\end{aligned}
$$


packing season is virtually over. The extremely early dates of Babylonia are Ibráhímí, Haláwí Makkáwí, Balabán, Makkáwí Ashqar, Bárbản, Badinjání and Sultání, while Záhidí and the Busreh Haláwí will have to be put on the edge of the list.

The later dates, on the other hand, continue to ripen well up to December first. Khasáb, Hilálí, Shatwí, Lúlúí and 'Amámet al Qadhí can be had fresh in any quantity up to the middle of November at least.

The dates of the region average well in size, and the dry varieties, in particular, are conspicuously larger than the similar dates of Algeria; they are also of better quality, on the average, while the best of them reach a perfection that was never dreamed of in the Sahara. Babylonia's largest dates, I should say, are 'Awaydí, Bú Saba'a al Dra'a, Madaní, Sayyid Ibráhím and Ism'aíl Qadrí,-all of them rare.

Arab scientists classify the principal varieties as hot or cold, according as a long-continned and exclusive diet of them "burns" the stomach or not. The distinction is important in a country where people eat little except dates, but it will not be worth considering in the States, where a handful a day is a heavy ration. Khustáwi is universally considered the coldest date known: one can eat five pounds daily for a year and never feel them. Bárbán, at Baghdád, is considered the hottest, but is valued, nevertheless, on account of its earliness. As a matter of fact, not only most of the varieties, but most of the choice varieties, are considered hot. Among the cold ones are Khadhráwí, Sukkarí, Shukkar, Amír Hajj, Sukkar Nabat, while Maktúm and Badráhí are placed in an intermediate class, neither hot nor cold, but satisfactory. Asharasí, Tabirzál, Haláwí, Záhidí, and Barhí, most of the other dates of sufficient importance to receive classification, are on the hot side of the ledger.

As to the best date of the region, Arabs agree in awarding the palm to the Khaláseh of Hasa* which, however; is little grown outside its original home. I think this judgment is correct. My own second choice is Maktúm or Tabirzál, but many of the Baghdádís swear by Sukkarí-in fact, that would probably have more votes than any other at the City of the Caliphs. Khustáwi has many admirers. The originator of the variety Khiyára declares that none can equal it. Those partial to dry dates affirm that nothing surpasses Asharasí. At Busreh, 'Awaydí and Barhí are tied for first place. Sultani is the choice of the Hilleh growers. Amir Hajj is esteemed, but the rare Jamál al Dín, Baqlah and Gul Husaini from the same region are considered quite as good, if not better. Those who have tasted Khasáwí al Baghal call it excellent. Brím is considered one of the finest known dates at Baghdád, while at Busreh it is held to be fit only for boiling. In short, it is all a matter of taste, but if one took Barhí, 'Awaydí, Khustáwí, Maktúm, Tabirzál and Sukkarí as the best of the region, he would not be far wrong; leaving the

* Cf. Palgrave, W. G. Narrative of a Year's Journey through Central and Eastern Arabia, vol. II, p. 172, London, 1865. 
others I have mentioned as second choice, with the incomparable Khaláseh always in a special place of honor.

As for the worst ones, the two Sáadas, Sharisí, Ja 'afarí, Hamráwí, Halái and Asshag will have to fight for the leather medal among themselves. One sometimes finds in the bazars worse dates than any of those, but they are merely seedling fruit. The varieties named are as bad as any one would care to perpetuate.

Methods of culture differ little in Babylonia from those in other Arab countries, and I therefore omit any deseription of it, particularly since it has been treated by Fairchild* fully and satisfactorily.

In transliterating the Arabic names of date varieties, I have followed the system now universally adopted by scientific men-namely, that consonants should be pronounced as in English and vowels as in the continental languages -e.g., Spanish. This system, which was elaborated by the International Congress of Orientalists at Geneva in 1894, has the merit of being both uniform and simple.

The following list, arranged in alphabetical order, contains the varieties which I was able to list in Babylonia, either from my own observations, or from the descriptions of native acquaintances; but as I have recently published $\dagger$ deseriptions of most of the varieties now in California, at some length, I omit these in order to save duplication. For the following Babylonian varieties the student should, therefore, consult my book on Date Growing:

Anjasi, "The Pyriform."

Asjbi' al 'Arús, "The Bride's Fingers."

Asharasi, "The Tall Growing."

'Awaydi, "The Little Big One."

Bajláni, named after a tribe of noted date-growers.

Badinjani, "The Egg-Plant Date."

Bárbán, "The Fair Persian."

Barhi, named after a hot wind supposed to ripen it.

Brim, (origin of name disputed).

Dubaini, named after the oasis of Dubai, near Baghdád.

Fursi, "The Persian."

Guntá, properly Qintár, "The Hundredweight."

Halawi, "The Sweet."

Halawi Makkáwi, "The Sweet Date of Mecea."

Hasan (or Husain) Effendi, (a man's name).

Hasáwi, from Hasa.

Ibráhimi, "Abraham's Date."

Khadhrawi, "The Verdant."

Khustami, "The Date of the Grandees."

* Fairchild, David. Persian Gulf Dates and their Introduction to America. Bul. No. 54, Bureau of Plant Industry, Washington, D. C., 1903.

+ Date Growing in the Old and New Worlds, by Paul B. Popenoe. West India Gardens, Altadena, Cal., 1913. 


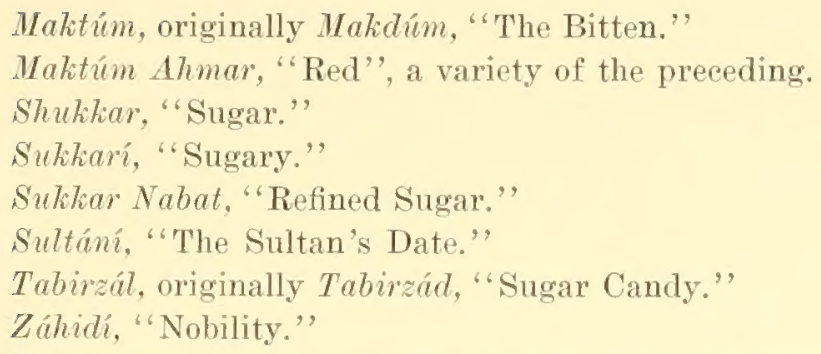

The varieties in the foregoing list are all to be found now in the United States. The following list comprises all the other varieties of which I could learn in Babylonia; they are not growing in the United States, unless so described, but many of them should be given a thorough trial as soon as possible.

\section{Other Babylonian Varieties}

'Abadli, "The Date of Abdullah" (a man's name), a large, soft date, light reddish-brown in color, grown principally in the oasis of Baqúbah, near Baghdád. Usually eaten fresh, but keeps well if packed tightly. Ripens about the middle of September. Quality good. Yield fairly heavy.

'Amámet al Qadhí, "The Kadi's Turban," a large, yellow, dry date, very thick in proportion to its length; ripens late in season and is of mediocre quality. Mostly eaten fresh, but not a common date. Seed large. It is occasionally picked when still soft and packed in skins.

Amir Hajj, "Leader of the Pilgrimage," a date practically confined to the oasis of Mandali on the Persian frontier. It is ranked among the best dates of Babylonia, partly because of its quality and partly because of its attractive appearance and its searcity. Nowadays it seems to be exported only in the form of presents. The few trees are in the gardens of wealthy men who refuse to sell offshoots from them, consequently the variety is not disseminated.

The palm is tall and graceful, but very delicate, requiring a great deal of cultivation and water; a shy bearer. It matures its fruit in midseason.

Many seeds of this variety have been planted in California, all efforts to secure offshoots having failed.

In form, the date is broadly oblong-oval to oblong-ovate, flattened at base, widest at or near eenter; apex rounded to broadly pointed, base flattened. Size medium large, one and one-quarter to one and three-eighths inches long, seven-eighths to one inch wide. Surface dry or nearly so, roughly undulating, slightly glossy where the thick bluish-gray bloom has been rubbed off; deep, rich orange brown in color, unusually translucent. Skin firm but rather thin, not easily broken, though tender; loosely folded, the folds rather prominent but only occasionally separating from the flesh; no blisters. Flesh three-eighths inch thick, of caramel consistency, translucent, light golden brown in color; fibrous lining of seed cavity yellowish cream colored, fibre tender 
and unnoticeable in the mouth. Seed rather small, three-quarters inch long by one-fourth to three-eighths inch wide, oblong to oblong-obovate, blunt at base, slightly tapering at apex; smooth; deep, dull brown in color; ventral channel almost or entirely closed; germ pore at or near center. Flavor very rich and pleasant, not so sweet as to be cloying nor so strong as to be objectionable. Although the date somewhat resembles Maktúm in appearance, the flavor is entirely different.

'Arab Siki, (Turkish), "The Arab's Phallus," a variety mentioned by G. Ghanimeh in an article on the Palms of 'Iraq in Al Machríq, No. 11, p. 480, Bayrút, June 1, 1907. I could not find this variety.

Asharasi Aswád, ("black"), a rare sub-variety of Asharasí at Baghdád. Form broadly obovate, sometimes almost spherical; base broad and flattened, apex rounded to very broadly pointed. Of very solid consistency, but not hard. Size medium large, length one and one-fourth to one and one-half inches, breadth one to one and one-eighth inches. Surface dry, rough, slightly glossy, deep purplish maroon in color, bloom unnoticeable. Skin rather dry, moderately thick but not tough, coarsely wrinkled indiscriminately, and toward apex separating from flesh in numerous folds and blisters. Flesh solid, gummy, one-fourth inch thick, translucent light brown under skin one-third of distance to seed, the rest light straw color. Slightly fibrous around seed cavity. Seed broadly oblong, blunt at base, rounded at apex, plump, elevensixteenths inch long, five-sixteenths broad, smooth, cinnamon brown in color, ventral channel open, rather shallow, germ pore slightly nearer apex. Flavor rich and nutty, quite similar to that of Asharasí.

Ashqar, "Sorrel," referring to its color. This is the Busreh name; at Baghdad the word is made feminine instead of masculine: Shaqra. A long slender date of rather above average size, sorrel colored, ripening in September. Considered good when fresh, but does not keep well. Bears heavily. Not common in either district.

'Ashuri, a name which indicates that the date ripens in the first ten days of the month,- - but I do not know which month. It is a very rare Baghdad soft date, resembling Khustáwí but a little larger. Ripens in midseason; yield good; the date is noticeable for its tender skin.

'Ashshaq, "The Preferable," I take to be the true form of the date vulgarly called "Asshag" at Busreh. It is a mediocre variety ripening in October. Long and slender, almost black; keeps well but is not good as rutab (fresh dates). Bears heavily. Not common.

Awashek. (a woman's name), originated in a garden owned by a woman of that name at Mu'adhdham, near Baghdád, and is confined to that neighborhood. Yellowish brown in color, long and of medium thickness; midseason. Opinions differ as to its value, some declaring it worthless while others represent it as a delicious fruit with notably tender skin.

Aweriha (?), variety reported from Hilleh, of which I could get no description. 
Azraq, "Brilliant," a good soft date principally grown at Mandalí and Badra. Form oblong-ovate, rounded at base, broadly pointed at apex. Size medium, length one and one-fourth to one and one-half inches, breadth at widest point, at or near center of fruit, five-eighths to three-fourths inch, Surface rather rough, light brown in color, glossy, bloom unnoticeable. Skin firm but thin, rather tough, loosely wrinkled indiscriminately, oceasionally blistered, but otherwise adheres closely. Flesh very firm and of caramel consistency, good texture, three-sixteenths inch thiek, translucent, light reddish brown in color, slightly fibrous near seed. Seed oblong, slightly pointed at both ends, three-fourths to seven-eighths inch long, five-sixteenths inch broad, smooth, grayish brown in color, ventral channel open but narrow. Flavor sweet but the taste of syrup rather more prominent than that of dates.

Banafshah,* "Violet Blossoms," a dry date of attractive appearance but ordinary quality, grown around Baghdád but more at Handalí. F'orm oblong, slightly swollen toward the apical end, the base bluntly flattened, the apex rounded or very broadly pointed. Size medium large, one and one-fourth to one and one-half inches long, five-eighths to three-fourths inch wide. Surface smooth or coarsely wrinkled longitudinally, dry, hard, dull purplish maroon in color with slight bluish bloom. Skin thin, dry, moderately tough, adhering closely except for an occasional fold, usually somewhat wrinkled toward apex and smooth near base. Flesh dry, solid, mealy, one-eighth inch thick, dull white in color, sometimes slightly soft near apex. No fibre. Seed very large, oblong, blunt at base and rounded at apex, one inch long, five-sixteenths inch broad, smooth, fawn colored, ventral channel open, deep, germ pore slightly nearer apex. Flavor sweet but lacking in character.

Baqlah, "The Pot IIerb Date" (?), a large, yellowish brown date with small seed, which ripens about the middle of September and is known as a heavy bearer. Considered best when tresh, but, also, packs well. It is rare, if known at all, in Baghdad, and seems to have originated sonewhere on the Persian frontier. Those who have eaten it call it delicious. I ordered some offshoots of this variety from Badra and received four specimens labeled "Daklieh," so I do not know whether I introduced it to California or not. Sayyid Salman Abatshí who is considered an authority on dates at Baghdád, declares it is the best variety in Babylonia.

Badami, "Almond-like" (Persian), a rare Baghdád solt date which is highly esteemed. Nedium large, light brown in color; ripens early in September. Eaten as rutab (fresh dates) or packed in skins or boxes.

Badráki, from the oasis of Badra, although those of Mandalí are considered better. The palm flourishes in a sandy soil and is rarely found at Baghdád, in fact, I was unable to secure any offshoots of it. The date is much liked by the Baghdádis, but the whole supply is shipped in. The palm

* This is the Persian word, but is usually heard at Baghdad, as are many other Persian words, because of the large Persian population there. The classical Arab form Banafsaj is, also, heard; it is merely a corruption of the Persian; by the time the word reaches Algeria it has degenerated to Balasfanj. 
is easy to cultivate, but bears moderately; it has been a decided snceess in Califoruia. Season, late September.

Form broadly oblong, tending to oblong-oval and oblong-obovate, hroadest hetween center and apex. Base sliglitly flattened, apex broadly pointed. Size medium to medium large, one and one-fourth to one and three-fourths inches long, seven-eightlus to one and one-eighth inches wide. Surface hard and dry, smooth to roughly undulating, rarely wrinkled; brownish straw colored, sometimes darker toward apex and lighter toward base. Skin hard, dry and brittle, acthering closely to flesh and rarely wrinkled or folded. Flesh three-eighths inch thick, light straw colored, very hard and solid, not mealy, free from fibre. Seed ohlong-elliptical, slightly tapering at base and pointed at apex, threefourths inch long, five-sixteenths inch wide, fairly smooth, deep hrown in eolor, ventral chamnel open, narrow; germ pore slightly nearer apex. Flavor remarkahly sweet and delicate, almost honey-like, with very little of the nutty Havor that characterizes Ashorasi.

Bayt al Sabuh, "Breakfast Food," a scarce Busreh variety of slight value. The fruit is large, short and thick, light brown in color, and ripens ahout October first. Principally eaten as rutal, the dried date keeps fairly well but is inferior. Heavy bearer.

Balabun, perhaps "The Date of Bán," a region in Arabia always famed for its dates. A small, short, hrown, soft date which seems to be confined to one garden at Baghlíd and is said by its possessor to ripen almost a month before any other. The palm is of rank growth, resembling a male in appearance, and hears well. 'The dates are eaten fresh, packed in skins, or cured to a caramel consisteney.

Bumi, "The Swectmeat Jar"* (Persian). An Oman variety, very rare at Baghdad. I met men who had heard of it there but nerer one who had actually seen it.

Bú Saba'a al Dre'a, "Father of Seven to the Cubit," deseribing its length. This is the name at Busreh and Abu'l Khasíl, at Baghdad it is called merely Saba'a al Dra'a. A long and slender variety of medioce quality, very rare and grown more as a euriosity than anything else. Dark hrown in color. The fresh fruit is not good, nor is it much better when fully mature.

Busrúu. "From Busreh," a varjety grown at Baghdád, but not common, although esteemed because it hears early (August). A large, soft date, of which two sub-varieties are distinguished, "Asfar" or yellow and "Ahmar," reded.

Chayun, "T'en-flavored" (Persian), a varicty of which I heard the name? only.

* 'This clerivation was given me in Masqat, and is quite legitimate. Bimi is one of the most fumous classical varieties, and all ancient authorities mention it in Babylonia; I can not prove, however, that the present Burm is identical with it. There scem to be two or more varieties confused under the latter name at present. The etymology of Birni is certainly not that given above.

+ Properly the word should be transliterated Dhim' 'There are three cubits in use at Busreh, of 18,25 and 27 in., respectively. 
Chibchab, see Kibkab.

Dafr al Ghazál, "Gazelle's Dung", a Busreh variety, very scarce, eaten only as rutab. Of medium size and slender, yellowish brown in color, ripening about September fifteenth. Quality good.

Degal 'Abbás, "The Date of Abbas" (a man's name). A rare but esteened Jusreh variety whose fruits ripen about October first. The date is small, long and slender, light brown in color. Bears at an early age and heavily; the fruit keeps well.

Degal 'Amad, "The Columnar", a Mandalí variety, of which a few palms exist at Baghdád. Very small, no larger than the end of one's finger, but of good quality. Light brown in color and of moderately soft consistency when cured, but usually eaten fresh.

Degal Khatin, "The Lady's Date," a searce and inferior Baghdád dry date, also eaten rutab. Yellowish-brown; midseason.

Degal Muza, "The Banana Date," a Busreh variety probably identical with Qush Múza of Oman. Fruit small, short and of medium thickness: same color as Khadhráwí. Ripens September fifteenth to twentieth. Eaten fresh; keeps well but is not so good when cured. Yield good. Most gardens of any size have a few trees of this variety to provide carly rutabs (fresh dates) for family use.

Dairi, said to mean "Of the world," i. e., "grown everywhere," but it is possible that it means the Monastery Date, referring to the famous Dair al Balah (Monastery of Dates) at Gaza (Ghazzeh) in Palestine, where the Lgyptian Hayání, called Birket al Hajjí in Ameriea, is mueh grown. If so, the Busreh Dairí would be Hayání (Birket al Hajjí). It is one of the commonest "soft and dry" dates of Busreh, but of inferior quality. It is sometimes packed in skins as a soft date. The offshoots come into bearing at an early age, but the yield is always rather light. Not eaten in the fresh stage. Ripens about October first.

Form oblong to oblong-ovate, widest near center, whence it narrows slightly to the broad and obliquely Hattened base, and more pronouncedly to the broadly pointed apex. Size large, one and one-half to one and seveneighths inches long, three-fourths to one inch broad. Surface almost smooth, translucent brownish red to light maroon in color, overspread with a thin, gray-blue bloom. Skin thick, tough, adhering closely except for occasional longitudinal or transverse folds; wrinkling almost none. Flesh firm, tender, one-quarter inch thick, translucent, deep amber colored. Seed oblong, blunt at base, slightly pointed at apex; one inch long, three eighths wide; smooth, light brown, ventral channel broadly open, germ pore two-thirds of distance from base to apex. Flavor sweet but lacking in character and with unpleasant after-taste.

When allowed to become dry, the date is similar to the above, save that the flesh around the base becomes whitish, opaque, granular and dry, sometimes extending in a layer around the seed cavity, almost to the apex of the fruit. 
Fimliquich, "The Filbert," an alternative name for Jaúzí.

Gul II usaini (Persian), The Rose (or F'lower) of II usaín (a man's name), an extremely rare variety from Mandali, on the Persian frontier; it is apparently unknown at Baghdid and Busreh. Large, soft, usually eaten as rutab ouly, and said to be superior to the better known Amir Ilajj of the same oasis,

IIalai, named after the village of IIala (?), one of the poorest of the Busreh dates; ripens early in Oetober, and bears heavily. A yellow, dry date, about the size of ILalíwí. Not common.

Hamruxi, an inferior Buspeh soft date ripening in the last week of September. Its name suggests its color, "reddish," in shape it is small and slender. socares, shy bearer. Cures well and can be kept six months.

IIrmúshigh, "The Date of IIanush" (a man's name), a rare Baghdád dry date of grood quality hut poor appearance. Form oblong to oblong-elliptical, broadest a little below center, hase flattened, apex rather sharply pointed. size medium large, one and three-eighths to one and five-eighths inches long, seven-eighths broad. Surface dry, roughly undulating, a dull, yellowish hrown in color, often tinged with magenta near hase; hloom unnoticeahle. Skin medium thick, tomen, dry, freely hlistored and folded, and not adhering elosely exeept around base. Flesh clear white or nearly so, changing to transheent amber brown near tip); three-eighths ind thick, solid, neaty but not mealy; fibre very slight. Seed oblong, ratlere slender, rounded at hases, hroadly pointed at apex, seven-eighths to one inch long, three-eighths to one-cutarter inch broad, smooth, aray-brown, ventral (hannel closed or nearly so, germ pore nearer apex. Flavor very sugary, slightly mutty, similar to that of Badrálíi and about as good. Ripens midseason.

Hilik. "Noonbeams," a delicious yellow date of the Persian Gulf, fairly common at Busreh, and provicling rutabs up to Deember. It has been suecessfully grown in California, but its late maturity is a drawback to its wide cultivation. Desceribed in Bul. ('al. Atate ('om. Hort., Jan. '14.

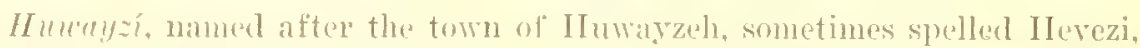
and frecuently confounded with 'Awaydi. A choice Buspeh soft date which is usually caten fresh; the Arahs say it is inforior when cured, lnut this statement is haxlly, justified. A fairly long, slender date, more or less similar to Ialáwi hoth in shape and color which is light brown. Ripens ahout the last week of september; the palm bears well from an early age, but is not common. Flavor delieate and pleasant. The fruit will leep for five or six months in good condition; experimental shipments made to New York have been surecessful.

*Literally, "Ihe Crescent Moon." The root is an ancient Semitic one, and it is interesting to note that it is found in the expression I Ialleluiah = Hallelu-Yah, $i$. e., I ord of the New Hoon; a liturgical phrase indicating that the ancestors of Aluraham were deroted to the worship of the moon. 
Ism'ail Qadri, (name of a man), a scarce Baghdád dry date which is also eaten in the rutab stage, and is esteemed. Bears well, late in August. Size large, color yellow, sometimes with a reddish-brown tinge.

Ja'afari, "Refined Gold" (also a man's name), a rare and bad dry date of the Baghdad district. Yellow in color; so astringent that it is eaten only by eamels.

Jamál al Din, "The Beauty of Religion," a Mandalí date, which some connoisseurs esteem the best of that oasis, very rare at Baghdid. It is the earliest of the choice Mandali dates to mature (August), and is usually eaten fresh, but occasionally preserved in skins. Light brown in color, fairly large in size. There is said to be no commerce in this variety, but wealthy proprietors at Mandali each have a few trees for their own use.

Jaúzi, "Like an English Walnut," a name which well describes both shape and color. An excellent dry date of the Baghdád district, not eaten in its soft state; hears heavily, shortly after midseason. Not very common. It is sometimes called Findúcíeh, or vulgarly Bindúcíeh.

Form broadly oval to almost spherical, widest near center. Base rounded, apex blunt to rounded. Size medium large, one and one-fourth to one and three-eighths inches long, one and one-eighth to one and one-fourth inches wide. Surface very rough, hard, dry, yellowish brown in color tinged with magenta; bloom unnoticeable. Skin medium thick, tough, deeply and coarsely wrinkled but adhering to flesh except for an oceasional blister around apical end. Flesh very solid but not inealy, one-fourth inch thick, translucent brownish amber close to skin, ereamy white toward seed; white portion threefourths of whole. Seed broadly oblong, plump, three-fourths inch long, threeeighths broad, both ends broadly pointed; smooth, russet, ventral channel closed. Flavor sweet, nutty, mild and rich. The fruit varies considerably, however, and very inferior dates of this variety are sometimes found in the bazar.

Kákáwáni, also spelled Kikawani and Chichawani, a variety mentioned by Ghanimeh but unknown to me. The name is Persian; a lexicographer says it means "excellent; applied to dates which have no seed." 'This is confirmed by Al Hamdaní, who gives in his "Deseription of Arabia" (10th century) a list of Busreh dates and among them: "Al Sisa, aud it is called lyy the Persians Kíka and Chícha and by the Arabs Al Fakhix (the fine) and probably it has a defective seed * * which can be eaten." I suspect that this variety is merely a Shis [An unfertilized or unpollinated date-CEd.].

Kand Kaur, "The Bull's Penis" (Persian), a rariety of which I heard the name only.

Khalasch, "Quintessence," the date of Hasa in Arabia, considered by Persian Gulf Arabs to be the finest in the world. It is extremely rare at Baghdád; at Busreh it is being planted a little more extensively of late years, but is not yet common. The quality of the fruit at Busreh is rather inferior; 
it undoubtedly prefers a sandy soil. At Baghdád the growers claim its quality shows no deterioration; the aunual yield is from 100 to 150 pounds.

I secured about 400 palms of this variety from Oman and IIasa; it is fully deserilsed in 13ul. Cal. State Com. IIort., Jan. '14.

Khanayzi, (name of a tribe), an Oman variety, oceasionally found at Busreh. Described in Bul. Cal. State Com. IIort., Jan. '14.

Khasib, "The Abundant Producer," a variety that seems to be native of Oman, but is now becoming fairly common at Busreh, where it is valued hecause of its late maturity - fresh dates can he lad from it until almost the first of December. It is rarely eured.

In the bazar the date is usually secn attached to the cluster, and before softening is of a bright, rose-red color, ovate-elliptical in form, widest near the middle and tapering slightly toward both ends. As it softens the skin becomes translueent and assumes a deep, reddish amber color, becoming sticky from the exudation of syrup.

The following description is of cured dates of this variety obtained in the Busreh market: Form broadly oval to broadly ovate, widest at center or slightly nearer basal end, thence tapering to the narrow, flattened base and the broadly pointed apex, size medium, length one and one-fourth inches, breadth seren-eighths inch. Surface irrexular, reddish brown to prune purple in color, overspread with a thin bluish hloom; skin moderately thick, tough, coarsely wriukled, transwersely and longitudinally, but generally adheriug closely to the flesly; Hesh firm, tender, one-fourth to one-eighth inch in thickness, translueent, deep amber colored; seed ohloug, round or blunt at base, pointed at apex, three-fourths inch long, five-sixteenths broad, smooth, deep grayish brown in eolor, ventral channel open, shallow, germ pore nearer hase than apex; Hatvor sweet but lacking in character and with a rather strong after-taste.

Thasaut al Baghal, "The Ass's Testicles," a variety said to be common and esteemed in Madina. It was introdnced to MIesopotamia several generations ago but has never hecome widespread. The date is of large size, brown in color: eaten either fresh or cured.

hliyara, "Cuember-like" (Persian), a soft date originating with Mullah Nají of Baghdád, who claims it is the best in Babylonia. Long, slemder, brownish-yellow, with a small seed. A heavy bearer and the bunches are very large; ripens in August. The tavor when fresh suggests that of a cucumber: packs and keeps well. Very rare.

ribliab, often spelled (and pronouneed) Chibchath or Chipehap. The word is Persian but its derivation uncertain; the hest native lexicographer" merely says it means "a palm which lets its fruits fall before they are ripe." I incline to the meaning, "The Date of the Chab tribe (properly Kab, a powcrful and widespread tribe of nomads) on the left chib; (this is, the left bank of the Tigris)." It is a fairly common date throughout the Persian gulf"; some-

* Al Muqaddisí (died 985) who lists 15 varieties of Busreh dates in his book "Mhsan al 'Taqásim" mentions Baydh al Baghal, "Ass's Eggs," which is very likely the same variety. 
times eaten in a half ripe stage but usually boiled to form what is called Kharak Polihta in Persian and Khalál Matbukh in Arabic, in which state it forms a considerable article of export to India. The date ripens about October first, and the yield is large.

Form oblong-elliptical, widest near center, thence narrowing slightly to the flattened base and broadly pointed apex; size large, one and one-half to one and seven-eighths inches long, seven-eighths to one inch broad; surface hard, rough, golden brown in color; skin thick, hard and brittle, with many deep longitudinal wrinkles and a few transverse ones, but adhering very closely to the Hesh, which is hard and dry, coarsely granular, five-eighths inch thick, brownish-white, opaque; seed oblong, blunt at base and rounded at apex, one inch long, five-sixteentlıs wide, fairly smooth, cinnamon brown in color, ventral channel almost closed, germ pore slightly nearer apex than base; flavor sweet but somewhat astringent. This deseription was made from boiled specimens.

Lúlui, "Pearly," sometimes spelled Lilwee, following the vulgar pronunciation. One of the latest varieties, if not the latest, to ripen at Busreh (November), usually eaten when soft. Sometimes eured but will keep only a month or two. A heavy bearer.

When fresh the variety is dull yellow in color, the flesh soft, fairly sugary and of good flavor. When cured, the fruit is broadly oval to broadly ovate, sometimes almost spherical, widest at or near center, rounded toward the rounded base and rounded or broadly pointed apex. Size small, length seveneighths to one inch, breadth at widest point seven-eighths inch. Surface almost smooth, brownish purple to purplish brown in color, bloom very slight; skin moderately thick, tough, usually not wrinkled but separating from the flesh in oceasional slight folds or blisters. Flesh soft, syrupy, three-eighths ineh thick, translucent, deep, brownish amber colored. Seed oblong, rounded at both ends or broadly pointed at apex; three-fourths inch long, three-eighths broad, smooth, grayish brown, ventral channel open near base only, germ pore nearer apex than base. Flavor sweet and moderately rich; pleasant.

Madani, "From Madiua," although it is said to have been brought to Baghdád from Mreeca by returning pilgrims. Sometimes qualified as Madaní almar (red). A long and very large date of a reddish brown color, said to be a heavy bearer; ripens midseason. Can be eaten at any stage, but is preferred when only about half ripe. Sometimes cured and packed in haskets. Said to be the largest date at Baghdad; very rare. The palm is characterized by a particularly thick trunk.

Makkúu, "From Mecea." 'Two varieties of soft date are designated by this name around Baghdád. 'The commoner is Makkáwí ahmar (red), scaree at Baghdád but said to be more plentiful in some of the outlying oases. IIedium size, good quality and large yield; ripens early in September. Eaten 
fresh or packed in skins. Mlakkáwi ashqar (sorrel) is probably only a subvariety of the same, ripens a little earlier, and does not keep.

Malquiti, a variety reported from IIilleh, of which I could get no particulars. 'The name means "that which is picked up off the ground after it has fallen.'

M'au, "Like an Intestine," a long, yellow, Baghlád variety, possibly a dry date, lont is usually eaten when soft. Ripens early in September and is a favorite with the people because of the honey-like character of its flesh. IIas been famous for centuries; its name is a classic.

Mulaffaf, "The 'Twisted," a small yellow dry date of Baghdád, remarkable for the spiral wrinkles of the skin, which make it look as if it had been twisted. Very rare. Eaten either fresh or dry.

Nabaiti, named after a man or a town, a good but not common Busreh variety which seems to be on the border line between soft and dry dates. Ripens about October first. Good when fresh; must be dried in sun with eare, if it is eured at all, and even then does not keep well. Shy bearer and recpuires more time to come into bearing than do most ofishoots.

Form broadly ohlong, obliquely Hattened at hase and broadly pointed at apex; size large, length one and one-halt to one and three-quarters inches, breadth seven-eighths to ou ineh. Surfuee somewhat rough, glossy, translueent deep golden brown in color, bloom almost none. Skin medium thick but not tough, only slightly wrinkled but abundantly folded longitudinally and separating from flesh, which is firm, sometimes ahnost granular, thick, reddish amber close to skin, changing to light amber close to seed, not very translucent. Seed slender oblong-elliptical, pointed at both ends, one inch lone, one-fourth wide, smooth, gray brown, rentral channel narrow. Flavor sweet. much resembling some of the grood dry dates.

Nirsi, from the village of Nirs (?*), a good soft date grown in various districts on the rivere but apparently not at either Bayhdad or Busreh. Ripens in the latter part of september; keeps well.

Form oblong, slightly wider toward hasal end, rounded or slightly thattener at hase, rounded to broadly pointed at apex. Size medium, length one and one-fourth to one and one-half inches, hreadth five-eighths to threeguarters inch. Surface irregular, glossy, translueent light brown varying to orange brown; bloom unnoticeable. Skin thin, firm, tender, loosely wrinkled but adhering rather closely. Flesh firm, of caramel consistency, full of syrup, translucent, deep reddish amber in color, one-fourth inch thick, slight amount of fibre in seed cavity. Seed oblong-elliptieal tapering very slightly toward hoth ends, length thirteen-sixteentlis inch, hrealth one-quarter, slightly roughened, grayish brown, ventral channel very shallow. Flavor rich, somewhat like that of Khadhráwí.

* Al Hamdani mentions a variety "Nirsián," from the same root. 
Qaranfal, "Like a I'ink (the flower)," possibly in odor. A large, yellow, dry date of good quality at Baghdad, which ripens early in September, and can be eaten either fresh or dry. Bears well. Scarce.

Qurret Asharasi, "The Coolness (i. e., delightful freshness) of Asharasí," a Baghdád variety which is distinguished from Asharasí only by its slightly inferior size; they are sold indiseriminately together. Scarce. According to native idea, this variety is particularly sensitive to the odor of melons, and if one eats such a fruit under the palm, while the dates are unripe, they will all drop.

Riháwi, "The Fragrant," a Baghdád dry date, also eaten in its soft state. Sorrel colored, of medium size and good quality; ripens early in September; bears well; not common.

Sa'ada Aswád, "Black IIappiness," a common Baghdád dry date of poor quality, but as it bears leavily it is considerably sold as food for asses. Form oblong-elliptical, flattened at base, widest near center, broadly pointed at apex. Size medium, length one and three-eighths to one and five-eighths inches, breadth three-fourths inch. Surface almost smooth, dry, slightly glossy, maroon purple in color, hloom unnoticeable. Skin moderately thick, tough, usually not wrinkled, but with a few folds and undulations; adheres closely to the flesh, which is firm, solid, one-eighth to three-sixteenths inch thick, light brownish amber in color, translucent. Seed oblong, rounded at base, rounded or broadly pointed at apex, seven-eighths inch long and fivesixteenths broad, quite smooth, russet in color, ventral channel almost closed. Flavor rather strong. This deseription was made from good specimens; much of the fruit in the hazar is smaller, drier and in every way inferior.

A sub-variety called Sa'ada Hamra (red) is distinguished, but it differs only in being lighter in color, and is not common.

Saivir, "The Fibrons" (?), one of the most widely grown dates in Babylonia, although of inferior quality. It is also called Usta'amrán, and by that name is usually known at Baghdad; some experts profess to see a slight difference between the two, lut their efforts are hardly successful. At Muhammarah this name is usually corrupted to Sa'amran; Sta'amran and Sambran are other vulgar pronunciations sometimes heard. The date is exported to America to a limited extent; plays an important part in native trade in the Persian gulf, and is the principal date grown on the Euphrates and the middle Tigris. It bears heavily, shortly before the first of October at Busreh, and will keep for a year or more. Said to do hest in a sandy soil.

Form broadly oblong to oblong-elliptical, widest at center or slightly nearer apical end, whence it narrows almost imperceptibly toward the flattened base and broadly pointed apex. Size medium to medium large, length one and one-fourth to one and five-eighths iuches, width three-fourths to seveneighths inch; surface almost smooth, translucent, glossy, dark, orange brown in color, bloom almost unnoticeable; skin rather thick and tough, smooth except for oceasional wrinkles or longitudinal folds in which it separates from the 
flesh, which is rather soft, syrupy, one-fourth to three-eighths inch in thickness, decp amber colored, with considerable tender fibre around seed; the latter broadly oblong, rounded to blunt at both ends, three-quarters inch long, fivesixteenths broad, fairly smooth, grayish brown in color, ventral channel nearly closed, germ pore nearen base than apex; flavor very swect, not cloying, but not rich or distinctive in any way. 'The dark color of the date is its principal drawback. Has done well in United States.

Saba'a al Dra'a, see Bú Sala'a al Dra'a.

Sayyid Itrithm. (a man's name), is one of the largest of the Baghdad soft dates, but rare. Long in proportion to its width; light brown in color; ripens midseason; eaten fresh or cured; bears heavily.

Shaqra, see Ashriar.

Shakker, "Sugar," often ealled Shakkarí," an inferior Busreh soft date. not to be confounded with those of similar name at Baghdad. Of medium length and slender, light brown in color, ripening late in September; a slyy bearer; not common. Eaten principally fresh, but will keep a month if dried.

sharisi. "Of a had disposition," a fairly common Baghdad variety but on account of its poor cuality is usually eaten only by animals, for which reason the cultivator usually does not pollinate it. A long and slender but small date, light hrown in color; can loe eaten fresh or packed in skins or boxes. It is often ealled shís, "unfertilized."

shatur, "Wintry," the latest of the Baghdad dates to ripen (Novemher) but of fairly good quality. Usually caten fresh, but keeps well. Not common.

Form oblong, widest at center or toward basal end, flattened at base and bunt to hroadly pointed at apex. Size medium, length one and one-quarter to one and one-half inches, breadth three-fourths to seven-eighths inch. Surface dry, roughly undulating, opaque dull magenta in eolor near base changing to translueent deep amber brown near apex; bloom very slight, blue gray. Skin dry, firm, rather thick and tough, coarsely wrinkled and blistered. adhering closely around base but often separating toward apex. Flesh solid, meaty, three-ejghths inch thick, translucent amber hrown in color, rather fibrous around secd, which is oblong, slightly swollen in center, base and apex rounded, length seven-eighths inch, breadth three-eighths; smooth; light

* This, again, is a Persian word; the Arab form "sukkar" is, also, in use at Baghdad, loth for the article sumar, and as the name of a date variety. Our word "sugar" is, of course, of the same origin, all three forms deriving from the Sanskrit cakara, which meant either sugar or-sand! One of the commonest Arab methods of forming a date varietyname is to make an allusion to sngar in some way; such is the excellent Baghdad variety Tabirzál, which was originally Tabirzád or Talorzadh, a Persian word again. Cf. a classical Aral, lexicographer"s definition of "sukkar": "A certain sweet substance, well known; it is hot and moist, according to the most correct opinion; but some say cold; and the lest sort of it is the transparent, called 'Tabaradh; and the old is more delicate than the new; it is injurious to the stomach. engendering vellow bile: hut the juice of the lenon and orange counteract its noxiousness; it is said to be a word recently introduced, lut some say that it oceurs in one Tradition" (of Muhammad. "The use of a word by the Prophet is the highest recommendation it can have for etymological respectability). 
brown; ventral channel open but shallow, germ pore slightly nearer apex. Flavor rather strong, but nutty, somewhat similar to that of a good dry date. Sin Mufta, a variety mentioned by Colvill,* which I could not identify.

Shuxaylhi, "The Little Bees' Date" (?), a Busreh soft date resembling Khadhráwi but a little smaller. Ripens in October; not good when fresh but fairly good when cured; keeps eight or nine months. Scarce and a shy bearer. Tabashir, "Calcareous," probably from its chalky color, a variety of which I could get no more than the name. Donbtless a dry date.

Ukht Badra, "Badra's Sister," a name which indieates the similarity of this dry date of Baghdád to the distinct and commoner Badráhí. A rare variety, but sometimes found in the bazar.

Form oblong, slightly wider toward apical end, flattened at base and rounded to broadly pointed at apex. Size medium large to large, one and one-fourth to one and five-eighths inches long, seven-eighths to one inch wide. Surface dry, hard, smooth or somewhat undulating, dull yellowish brown in color, sometimes brownish yellow. Skin thin, dry, rather tender, occasionally slightly wrinkled or creased. Flesh three-eighths inch thick, light yellow near skin, changing to silvery white ncar seed; solid and meaty, but neither mealy nor brittle; dry, slightly fibrous around seed. Seed broadly oblong, rounded at base and aper, seven-eighths inch long, three-eighths wide, smooth, gray brown, ventral channel deep, germ pore slightly nearer apex. Flavor sweet and nutty.

Usta'amran. "The Date of 'Amr the Expert"' ('Amr is a common man's name). A synonym for Sáyir, q. v.

Umm A jrabch, "Mother of Quantity" (the ajrabeh is a grain measure containing 768 pounds) or "Mother of the Mange". If taken in this last sense, the name probably means that the palms of this variety are partieularly affected by the Parlatoria scale, which is colloquially known as "date-palm mange". A rare Baglidád soft date, much similar to Khustáí in appearance, but a little smaller. Ripens in midseason. Noted as a heavy bearer, as the first signification of its name would indicate.

Umm al Sawani, "Queen of the Table" or, more literally, "Mother of Platters". The name is collorqually prononneed Umuswani. A small, short, fat date known at Baghdád, but confined to a few gardens. It is eaten only in the fresh or rutab stage, when its color is a brownish yellow.

'Uyun Ayub. The latter word is the name, in Arabic form, $f$ of the Biblical Jol, the former has some fifty meanings in addition to its primary one of "eyes," As Job's Eyes seems senseless, I suggest (without any definite warrant from Arab sources) the translation "coins" which is etymologically

* In Jour. Iinn. Soc. London, pol. X1 V, p. 50.5.

+ The translators of the King James version of the Bible blindly copied Martin Luther in transliterating proper names, without stopping to think that the difference between German and English was wholly misleading in such cases as this. Job and Jacob would pass in German, where they correctly give the oriental pronunciation; but in English, with a different value for $j$, the translators should certainly have written Yob, Yacob, etc. 
entirely justifiable. The name could then be linked to the Arabic tradition given by Shaykh Jalal al Dín (15th c., A. D.) in his Commentary on the Koran, and dsewhere, that Job had two threshing floors, one for wheat and one for barley, and that after his prosperity had been restored, God sent a aloud over each of these threshing floors, raining gold pieces on one and silver pieces on the other, until they were wholly covered. The fruit which bears this mame is a rather small, yellow, dry date of Baghdid, scarce but esteemed. It ripens in midseason and the yield is said to be average.

Zahriych, "Flowery" or "Brilliant," a variety mentioned by Ghanimeh, lut unknown to me personally.

In addition to these, Dr. Zwemer mentions the following as being dates of the Busreh region: "Mother of I'erfume," "Sealed Up," "Red Sugar," "Pure Daughter," and "Daughter of Seven." I can not be certain of these identifications; but "Mother of Perfune" may be Ríháwi "Sealed Up" is probably Maktum; and "Daughter of Seven" is probably the same as "Father of Seven to the Cubit."

I may add that of the 111 varieties of dates deseribed in Baghdad by native writers of the eighth, ninth aud tenth centuries, and collected by Pére Anastase Marie of the Camelite Mission, Bagldad, $\dagger$ not more than fifteen or twenty ean be identified definitely as existing up to the present day. Some of them are probably now going under other mames; but no douht most of them have become extinct, as better varietics took their places.

\section{MALE VARIETIES.}

The principal variety of male date palm in the Buspel region is Ghanamí, "IBushy Ilead," which gives pollen in its third year, blooms early in the season, and produces from twenty to thirty spadices annually.

Other male varieties of this region are Inukri, whose name signifies, probaluly, "what is laid by in times of seareity" and points to the storing of pollen from year to year (although such a practice is extremely rare in Babylonia). Wardí, "Long Haired", and Sumaysmí, which is probably a colloruial promunciation of Shumaysmi, "little Sunburst," in allusion to the thick crown of foliage.

At Baghdád a dozen or more varieties of males are distinguished, merely hy the name of the female variety of which they are originally supposed to have been seedlings (although now propagated by offshoots, of course). The best of these is Asharasí, which sometimes bears forty or fifty spadices, the Arabs clain; and they declare that not only is the yield of fruit heavier when this variety of male is used for pollination, but that the flavor of the dates is also better. It is, accordingly, the only variety planted by con-

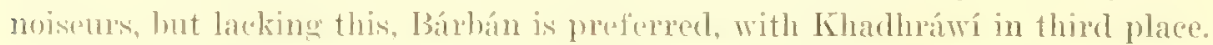

In importing specineus of the male Asharasi to California, I endeavored

*Zwemer, S. M., in "Arabia, the Cradle of Islam." New York, 1901.

† See Loghat el Arab, XI, 509, Baghdad, Mai, 1913. 
to avoid confusion with the female by dropping the last syllables and adding the Arabic worl for male; so it now appears as Ashar Fahal.

It is worth noting that the classical writers do not, apparently, know any named varieties of male, but mention merely "Fahal" or, in the plural, "Tahálníl." 



LIBRARY OF CONGRESS

0 0214863844 